\title{
What and where are the active sites of oxide-supported nanostructured metal catalysts?
}

\author{
Min Wang, Feng Wang* \\ Dalian National Laboratory for Clean Energy, State Key Laboratory of Catalysis, Dalian Institute of Chemical Physics, Chinese Academy of Sciences, \\ Dalian 116023, Liaoning, China
}

\begin{abstract}
The oxide-supported metal catalysts constitute the most investigated catalyst in both academia and industry. This perspective highlights recent research progresses on the topic, which may shed light on the nature and location of the active sites.

Keywords: Supported catalyst; Nanoparticle; Metal support interaction; Perimeter atom; Interface

Received 30 December 2013. Published 20 April 2014.

(C) 2014, Dalian Institute of Chemical Physics, Chinese Academy of Sciences. Published by Elsevier B.V. All rights reserved.
\end{abstract}

Oxide-supported metal catalysts are important catalysts that are much investigated in academia and industry [1-4]. When these catalysts are prepared by traditional techniques, they comprise a heterogeneous population of particles, nanoclusters, subnanometer species, and isolated atoms/ions on the support surface, which make the identification of the active sites difficult. The catalyst support generally has three functions: (i) it provides a thermally stable and mechanically robust platform for metal particle dispersion [5]; (ii) it provides a suitable environment for mass transfer (large pores, hydrophilic/hydrophobic surface) [6]; and (iii) it accelerates catalytic reactions via the so-called strong metal support interaction (SMSI) [7]. Recent studies have advanced knowledge on the role of the support in catalysis [8], and these have been well reviewed [9]. The support can modify the electronic state of the metal by electron transfer between the metal and support, to influence catalytic performance [10]. The knowledge gained has shed light on the two basic questions for oxide-supported metal catalysts: what is the active site and where is it located?

Oxygen vacancy sites on reducible metal oxides, such as $\mathrm{MgO}$ and $\mathrm{MoO}_{x}$, can stabilize negatively charged metal species. Häkkinen et al. [11] reported that gold octamers (Aus) bound to
F-center defects on $\mathrm{MgO}(001)$ are the sites that catalyzed the low temperature oxidation of $\mathrm{CO}$ to $\mathrm{CO}_{2}$, whereas the clusters deposited on non-defective magnesia surfaces are chemically inert. Charge transfer from oxygen vacancy sites to the deposited metal clusters underlies the catalytic activity of the gold octamers $\left(\mathrm{Au}_{8}\right)$. This charge activates the $\mathrm{CO}$ molecule by the back donation of electrons to the $\mathrm{CO}$ antibonding orbital. Wang et al. [12] recently found that surface-confined electrons in the oxygen vacancy sites can be transferred to the supported $\mathrm{Au}$ nanoparticles on partially reduced $\mathrm{MoO}_{x}$ (Fig. 1). As a result, the gold species is negatively charged. This species is responsible for the formation of the active oxygen species, for example, superoxo- or peroxo-species, in the oxidative dehydrogenation of alcohols to aldehydes and ketones.

Ceria $\left(\mathrm{CeO}_{2}\right)$ has wide applications in catalysis due to the easy formation of oxygen vacancy sites on it at low temperature $[13,14]$. Interactions between $\mathrm{CeO}_{2}$ and the supported

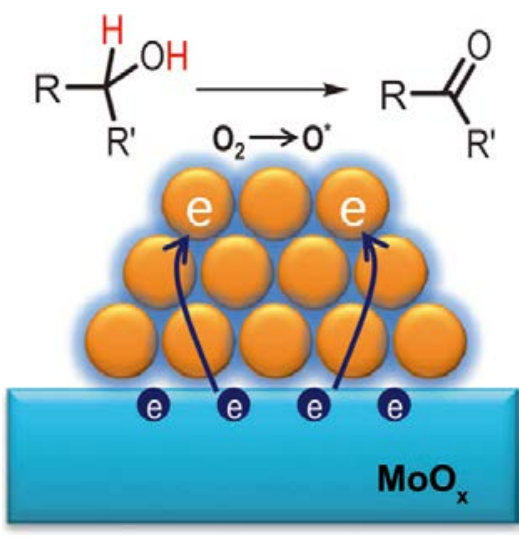

Fig. 1. Electron transfer from partially reduced $\mathrm{MoO}_{x}$ to gold nanoparticles. Reproduced from Ref. [6] with permission from Wiley.

\footnotetext{
* Corresponding author. Tel/Fax: +86-411-84379762; E-mail: wangfeng@dicp.ac.cn This work was supported by the National Natural Science Foundation of China (21303189, 21273231, and 21233008), and the Hundred Person Project of the Chinese Academy of Sciences.
} 


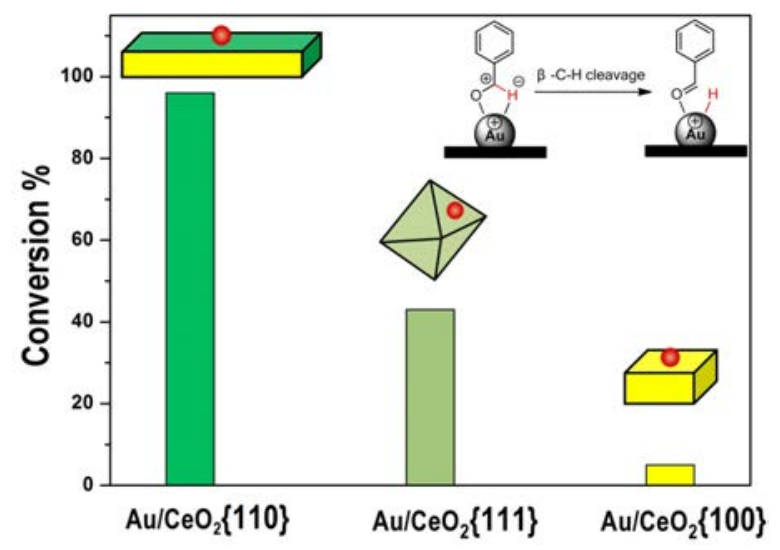

Fig. 2. Gold deposited on the $\{110\}$ phane of ceria showed the highest activity for alcohol oxidation. Reproduced from Ref. [9] by permission of The Royal Society of Chemistry.

metal greatly enhanced the rates for a number of reactions, such as $\mathrm{CO}$ oxidation, alcohol oxidation, and the water gas shift (WGS) reaction [15-17]. It is commonly recognized that the metallic particles are the active sites. Fu et al. [18] showed that the active species in the WGS reaction is the charged metal species on the $\mathrm{CeO}_{2}$ supported catalyst and that the metal nanoparticles did not participate in the reaction. Recently, we found that the active metal species are mainly located on the $\{110\}$ surface plane of $\mathrm{CeO}_{2}$ (Fig. 2) [19]. However, the exact nature of the active atoms and their location are still unclear.

A recent work by Murray and coworkers [20] suggested that the atoms at the interfacial rim of the nanoparticle and support $\left(\mathrm{CeO}_{2}\right)$ are the active sites. A similar site has been proposed for other catalysts [21]. The reaction rate can be enhanced by increasing the length of the ceria-metal interface. Murray and coworkers [20] prepared three different sizes of nanocrystals $\left(\mathrm{Ni}, \mathrm{Pd}\right.$, and $\mathrm{Pt}$ ) and deposited these on an inert support, $\mathrm{Al}_{2} \mathrm{O}_{3}$, and an active support, $\mathrm{CeO}_{2}$. The preparation of the catalyst was carefully controlled to give a narrow site distribution and similar shape. This was critical for making a computer model of the interface between the nanocrystal and support for comparing the performance in $\mathrm{CO}$ oxidation. For the $\mathrm{Al}_{2} \mathrm{O}_{3}$ support, no difference was observed in the catalytic activity between the differently sized particles when this was normalized per number of metal atoms. However, they found that the activity of the $\mathrm{CeO}_{2}$ supported catalysts displayed a strong size dependence on the three metals. The smaller particles were more active than the larger ones. This showed that a structural difference in the particles led to different active sites for the reaction.

From the model of the interface between the metal particle and support, they calculated the number of perimeter atoms and correlated these interfacial atoms with the catalytic activity. They found that the activity increased with an increase in the fraction of interfacial atoms (Fig. 3). This indicates that the perimeter atoms are the active sites for the $\mathrm{CO}$ oxidation in $\mathrm{CeO}_{2}$ supported metals.

Concerning the exact nature of the active atoms and their location, the above studies have together partially answered the questions although the debate will remain open. It is the catalytic environment created by the supported metal and

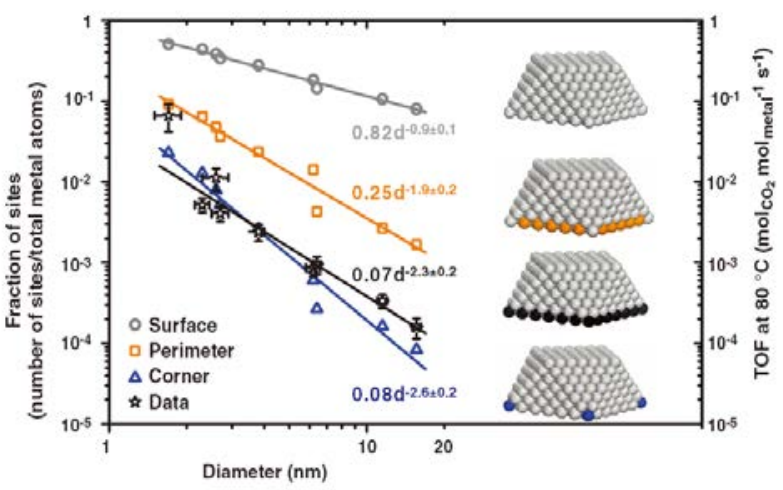

Fig. 3. Calculated number of sites for a particular geometry (surface and perimeter or corner atoms in contact with the support) as a function of Pd diameter and TOF at $80^{\circ} \mathrm{C}$ for the nine ceria supported samples. Reproduced from Ref. [10] with permission from AAAS.

support that plays a pivotal role in the catalysis. Charge transfer from or to the supported metal on the environment it is in contact with has the decisive effect, and this depends on the charge state of the support or additive. For a catalytic site located at the perimeter site of the metal and oxide, charge transfer easily takes place, and the transferred charge gets stabilized.

Over the past decade, significant advances have been made in oxide-supported metal catalysis, especially for the transformation of small molecules such as CO. These studies have emerged as powerful tools for understanding the catalytic nature of metal catalysts, in particular, the "what" and the "where" in the title. The rational preparation of metal particles using size, shape, and morphology controlled ways and their interaction with the oxide support are critical to the development of highly active and selective catalysts. Although much progress has been made in the past, more research is needed to be conducted. The challenges lie in the design and preparation of multifunctional and robust metal particles and their controlled immobilization on the support, which provides the control of the perimeter sites at the metal-support interface. This nanoor sub-nano-structure emphasizes the importance of the location of the active sites. In situ and operando combined characterizations are required to give timely feedback and information on the nano- or sub-nanoscale. Besides the use of model catalysts, the use of the complex information from real catalysts remains challenging, and these should be carefully analyzed, so that underlying useful information can be extracted. The work should not be limited to small molecules, and the broad application of metal oxide supported catalysts to large, complex, and multifunctionalized molecules targeting high atomic efficiency, yield, chemo-selectivity, and enantioselectivity in a one-pot system can revolutionize synthesis chemistry and open new avenues for green and sustainable chemical processes.

\section{References}

[1] Haruta M. Faraday Discuss, 2011, 152: 11

[2] Kuwauchi Y, Yoshida H, Akita T, Haruta M, Takeda S. Angew Chem Int Ed, 2012, 51: 7729 


\section{Graphical Abstract}

Chin. J. Catal., 2014, 35: 453-456 doi: 10.1016/S1872-2067(14)60073-5

What and where are the active sites of oxide-supported nanostructured metal catalysts?

Min Wang, Feng Wang*

Dalian Institute of Chemical Physics, Chinese Academy of Sciences

This perspective highlights recent research progress on oxide-supported metal catalysts, focusing on the nature and the location of catalyically active sites and giving insight into the challenges remained to be investigated in the further for this areas.

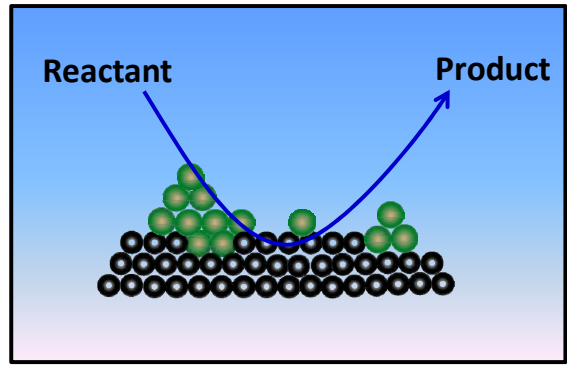

[3] Yang M, Allard L F, Flytzani-Stephanopoulos M. J Am Chem Soc, 2013, 135: 3768

[4] Ta N, Liu J Y, Chenna S, Crozier P A, Li Y, Chen A L, Shen W J. J Am Chem Soc, 2012, 134: 20585

[5] Chen C, Nan C, Wang D, Su Q, Duan H, Liu X, Zhang L, Chu D, Song W, Peng Q, Li Y. Angew Chem Int Ed, 2011, 50: 3725

[6] Wang M, Wang F, Ma J P, Chen C, Shi S, Xu J. Chem Commun, 2013, 49: 6623

[7] Hayek K, Kramer R, Paal Z. Appl Catal A, 1997, 162: 1

[8] Schubert M M, Hackenberg S, van Veen A C, Muhler M, Plzak V, Behm R J.J Catal, 2001, 197: 113

[9] Liu X Y, Wang A Q, Zhang T, Mou C Y. Nano Today, 2013, 8: 403

[10] Jenness G R, Schmidt J R. ACS Catal, 2013, 3: 2881

[11] Yoon B, Hakkinen H, Landman U, Worz A S, Antonietti J M, Abbet S, Judai K, Heiz U. Science, 2005, 307: 403

[12] Wang F, Ueda W, Xu J. Angew Chem Int Ed, 2012, 51: 3883

[13] Wang Y H, Wang F, Song Q, Xin Q, Xu S T, Xu J. J Am Chem Soc,
2013, 135: 1506

[14] Ta N, Liu J Y, Shen W J. Chin J Catal (塔娜, 刘景月, 申文杰. 催化学 报), 2013, 34: 838

[15] Zhang H L, Ren L H, Lu A H, Li W C. Chin J Catal (张慧丽, 任丽会, 陆安慧, 李文翠. 催化学报), 2012, 33: 1125

[16] Si R, Flytzani-Stephanopoulos M. Angew Chem Int Ed, 2008, 47: 2884

[17] Abad A, Concepcion P, Corma A, Garcia H. Angew Chem Int Ed, 2005, 44: 4066

[18] Fu Q Saltsburg H, Flytzani-Stephanopoulos M. Science, 2003, 301: 935

[19] Wang M, Wang F, Ma J P, Li M R, Zhang Z, Wang Y H, Zhang X C, Xu J. Chem Commun, 2014, 50: 292

[20] Cargnello M, Doan-Nguyen V V T, Gordon T R, Diaz R E, Stach E A, Gorte R J, Fornasiero P, Murray C B. Science, 2013, 341: 771

[21] Fu Q, Li W X, Yao Y X, Liu H Y, Su H Y, Ma D, Gu X K, Chen L M, Wang Z, Zhang H, Wang B, Bao X H. Science, 2010, 328: 1141

\section{研究视角}

\section{氧化物负载的纳米金属催化剂的活性位本质和结构}

\section{王 敏, 王 峰*}

中国科学院大连化学物理研究所, 催化基础国家重点实验室, 洁净能源国家实验室(筹), 辽宁大连116023

摘要: 氧化物负载的金属催化剂在学术界和工业界都是研究最为广泛的一类催化剂。本文主要介绍了最近几年关于这方面的代 表性研究进展，有望揭示负载型金属催化剂中活性位的本质和所处的位置。

关键词：负载型催化剂; 纳米颗粒; 金属载体相互作用; 周边原子; 界面

收稿日期: 2013-12-30. 出版日期: 2014-04-20.

*通讯联系人. 电子信箱: wangfeng@dicp.ac.cn

基金来源：国家自然科学基金(21303189, 21273231, 21233008); 中国科学院“百人计划”择优支持项目.

本文的英文电子版由Elsevier出版社在ScienceDirect上出版(http://www.sciencedirect.com/science/journal/18722067).

氧化物负载金属催化剂是学术界和工业界广泛研 究的重要催化剂 ${ }^{[1-4]}$. 采用传统方法制备的氧化物负载 金属催化剂, 其表面由分布不均一的各种颗粒、簇、次 纳米尺度物种以及高分散原子/离子组成, 催化活性位点 难以确定. 一般认为, 催化剂载体有三个主要作用: (1) 为金属颗粒分散提供一个热稳定和机械稳健的平台 ${ }^{[5]}$; (2)为反应传质提供一个适宜的环境(如大的孔结构和亲
水/憎水表面 $)^{[6]}$; (3)通过“金属-载体强相互作用”(SMSI) 促进催化反应 ${ }^{[7]}$. 近年来, 人们对载体在催化过程中作 用的认识不断深入 ${ }^{[8]}$, 对相关进展也进行了很好的综 述 ${ }^{[9]}$. 最新研究表明, 载体可通过与金属间的电子转移 来改变金属的电荷状态, 从而影响催化性能 ${ }^{[10]}$. 新的研 究结果为进一步阐明氧化物负载金属催化剂活性位的 本质及其物理结构提供了有益帮助. 
金属氧化物如 $\mathrm{MgO}$ 和 $\mathrm{MoO}_{x}$ 上的氧缺陷中心可稳定 带有负电荷的金属物种. Häkkinen等 ${ }^{[11]}$ 发现, 金纳米簇 $\mathrm{Au}_{8}$ 与 $\mathrm{MgO}(001)$ 上氧缺陷位(F-中心或颜色中心)键合, 形成催化 $\mathrm{CO}$ 低温氧化为 $\mathrm{CO}_{2}$ 反应的活性中心, 从氧缺陷 位到金属簇的电荷转移对 $\mathrm{Au}_{8}$ 催化活性影响很大, 这些 电荷反馈到 $\mathrm{CO}$ 反键轨道上以活化CO分子; 而沉积在无 缺陷 $\mathrm{MgO}$ 表面的金纳米簇没有催化活性. 最近Wang 等 ${ }^{[12]}$ 发现, 部分还原的 $\mathrm{MoO}_{x}$ 表面氧缺陷位中存在非离 域电子, 这些电子可转移到负载的金纳米颗粒上, 使金 物种带负电荷(图1). 该金物种可在醇氧化脱氢生成醛 或酮的反应中活化分子氧形成活性氧物种(如超氧物种 和过氧物种).

$\mathrm{CeO}_{2}$ 在较低温度下易形成氧缺陷位, 因而被广泛用 作催化材料 ${ }^{[13,14]} . \mathrm{CeO}_{2}$ 与负载金属间的相互作用可显著 提高催化反应速率, 如 $\mathrm{CO}$ 氧化、醇氧化和水气变换 (WGS) 反应 ${ }^{[15-17]}$. 一般认为负载的金属颗粒本身是活性 中心. $\mathrm{Fu}$ 等 ${ }^{[18]}$ 研究表明, $\mathrm{CeO}_{2}$ 负载催化剂上带电荷的金 属物种是WGS 反应的活性物种, 而金属纳米颗粒并不参 与反应. 我们进一步发现, 活性金属物种主要位于 $\mathrm{CeO}_{2}\{110\}$ 晶面上(图2) ${ }^{[19]}$. 然而, 活性位的确切本质和 物理结构尚不清楚.

最近, Murray等 ${ }^{[20]}$ 研究发现, 位于纳米粒子和载体 $\left(\mathrm{CeO}_{2}\right)$ 界面边缘位置的原子是活性中心. 在其它催化剂 上也发现有类似的活性位 ${ }^{[21]}$. 反应速率随 $\mathrm{CeO}_{2}$-金属界 面长度的增加而增大. Murray等制备了三种不同尺寸的 纳米晶粒 $(\mathrm{Ni}, \mathrm{Pd}, \mathrm{Pt})$, 并将它们沉积到惰性载体 $\mathrm{Al}_{2} \mathrm{O}_{3}$ 及 活性载体 $\mathrm{CeO}_{2}$ 上, 通过控制合成条件, 使得所制样品具 有窄的粒径分布和相似的外形, 然后建立纳米晶粒和载 体间界面计算模型, 比较 $\mathrm{CO}$ 氧化反应性能. 他们发现, 对于 $\mathrm{Al}_{2} \mathrm{O}_{3}$ 载体, 不同大小金属粒子的催化活性(以单位 原子活性计)没有差别; 但在 $\mathrm{CeO}_{2}$ 载体上, 这三种金属催 化剂活性表现出明显的尺寸效应, 小粒子的活性高于大
粒子的. 这表明不同的粒子结构导致不同的反应活性中 心.

通过建立金属颗粒与载体间界面模型, 他们计算了 边界原子数目, 并将边界原子数与催化剂活性相关联. 结果表明, 催化剂活性随着边界原子比例的增加而增加 (图3). 这说明边界原子是 $\mathrm{CeO}_{2}$ 负载金属催化剂上 $\mathrm{CO}$ 氧 化反应的活性中心.

尽管上述研究结果仍有争议, 但也在一定程度上回 答了催化活性中心本质和位置的问题. 负载的金属和载 体构建的催化环境在催化反应中起着重要作用. 负载金 属和与之接触的环境间的电荷转移具有决定性的影响, 这取决于载体或添加剂上的电子分布状态. 对于位于金 属和氧化物周边的催化位点, 电荷转移较易发生, 且转 移的电荷比较稳定.

近十年来, 氧化物负载金属催化研究已取得很大进 展, 特别是对于诸如 $\mathrm{CO}$ 等小分子的催化转化反应. 这些 研究为理解负载金属催化剂催化本质(特别是有关其本 质和位置)提供了重要参考. 采用合理的制备方法控制 金属颗粒的大小、形状和形貌及其与氧化物载体间的相 互作用, 对于开发高活性和高选择性的催化剂至关重要. 尽管相关研究已经取得较大进展, 但仍需进行更多工作. 如设计和制备多功能和稳定的金属颗粒并进行可控负 载, 达到调控金属-载体界面活性中心的目的. 这种纳米 或次纳米结构的存在使得确定活性中心的位置变得更 加重要. 需要运用原位组合表征手段, 以实时获得纳米 或次纳米粒子在催化反应中的信息. 除了采用模型催化 剂外, 实际催化剂复杂信息的获取更具有挑战性. 氧化 物负载纳米金属催化剂的研究应从小分子拓宽至更大 更复杂的多官能团底物分子, 提高有机反应的原子效 率、收率、化学选择性和对映体选择性, 为合成化学提 供新的方法和思路, 并为绿色和可持续化工过程提供支 持. 